\title{
DLL3 Positive
}

National Cancer Institute

\section{Source}

National Cancer Institute. DLL3 Positive. NCI Thesaurus. Code C140465.

An indication that DLL3 expression has been detected in a sample. 